Ewa Drzazgowska*

Chojnice

\title{
O fundamentalnych relacjach między prawdą, wolnością, dialogiem i budowaniem tożsamości - z perspektywy teorii mowy
}

\section{Trudności}

Człowiek wedle dobrze znanej i dlatego zbanalizowanej definicji Arystotelesa jest zōon logikon. To określenie chcę rozumieć w jego dosłownym, mniej rozpowszechnionym i może mniej zbanalizowanym sensie: nie jako 'istota rozumna', lecz jako 'istota mówiąca'. Tak na człowieka chce patrzeć w szczególności jeden z pierwszych filozofów dialogu, Ferdinand Ebner, wyrażając to swoje rozumienie tyleż prosto, co dobitnie: człowieka definiuje (oddziela od innych istnień) to, że „ma on słowo"

Mogłoby się wydawać, że tak stawiając sprawę, definitywnie coś chcę rozwiązać. I owszem, stoją za tym określeniem pewne rozstrzygnięcia (na

* Dr Ewa Drzazgowska jest filozofem i germanistką. Pracuje jako wolna tłumaczka i autorka, realizuje projekty społeczne i edukacyjne nastawione na poprawę jakości komunikacji, działa w Fundacji Zarzewie. Adres: Fundacja Zarzewie, ul. Książąt Pomorskich 30/9, 89-600 Chojnice; e-mail: ewa_drzazgowska@o2.pl.

${ }^{1}$ Ferdynand Ebner, Stowo i realności duchowe. Fragmenty pneumatologiczne (Chojnice: Oficyna Wydawnicza Fundacji Fuhrmanna, 2016), 24 i nn. Ebner podąża tu świadomie za XVIII-wiecznym filozofem języka/mowy, Johannem Georgiem Hamannem, w szczególności krytykiem Kanta i tegoż zaniedbań sprawy języka/mowy. Por. np. Detlef Otto, „Johann Georg Hamann", w: Klassiker der Sprachphilosophie: von Platon bis Noam Chomsky, red. Tilman Borsche (München: Beck, 1996), 197-213. 
przykład rozstrzygnięcie na rzecz prymatu mowy wobec myśli). Problem polega jednak na tym, że ta zwięzła Ebnerowska i zarazem Arystotelesowska formuła pewne rzeczy rozstrzygając, niesie ze sobą poważne trudności.

Wyraźne poczucie ich powagi miał we wczesnym średniowieczu Eriugena, mówiąc o tym, że człowiek jako istota rozumna i mówiąca (szedł tutaj za Ojcami greckimi) - tak wiele pojmując i przekazując - nie jest w stanie pojąć samego siebie (a co za tym idzie, także przekazać samego siebie)². Wittgenstein wyraził, moim zdaniem, to samo, mówiąc o (tajemniczych, jak się często podkreśla) przedmiotach prostych, o których co prawda mogę mówić, ale których nie moge wypowiedzieć, skoro ,zdanie mówi jedynie, jaka rzecz jest, nie czym jest" [t. 3.221] $]^{3}$. Sądzę, że te tajemnicze przedmioty proste trzeba rozumieć w pierwszej kolejności jako referentów słowa 'ktoś' (z tej perspektywy Wittgensteinowskie określenia 'przedmiot', 'rzecz' są w sumie dość niefortunne). O trudnościach związanych z określeniem człowieka jako istoty mówiącej, to znaczy, jak chcą Ebner i Buber ${ }^{4}$, osoby (a osoba to ktoś trudno się nie zgodzić z Wojtyłą), pisał również bardzo dobitnie Spaemann: „Słowo 'osoba' nie jest wyrażeniem gatunkowym, za pomocą którego określamy coś jako takie-a-takie [...]”. „To, kim jesteśmy, nie jest [...] w prosty sposób tożsame z tym, czym jesteśmy"'.

2 Jan Szkot Eriugena, Periphyseon, ks. II (Kęty: Wydawnictwo Marek Derewiecki), 187. Eriugena mówi w tym miejscu o intelekcie jako odpowiedniku Boga-Praprzyczyny. To jego powiedzenie interpretuję we wskazany wyżej sposób - powoływanie się Eriugeny na Ojców greckich sprawia, że taka interpretacja jest co najmniej niearbitralna. Na temat patrystycznych wyjaśnień dotyczących języka zob. Andrzej Bogusławski, Ewa Drzazgowska, Język w refleksji teoretycznej. Przekroje historyczne, t. I (Warszawa: Katedra Lingwistyki Formalnej Uniwersytetu Warszawskiego, 2016), 123-126.

${ }^{3}$ Ludwig Wittgenstein, Tractatus logico-philosophicus (Warszawa: PWN, 2000), 14.

${ }^{4}$ Martin Buber sformułował rzecz równie dobitnie, jak Ebner: ,[...] poza nią [mową] jesteśmy jako osoby unicestwieni”, cyt. za: Andrzej Bogusławski, Roztrząsania nadlingwistyczne (Warszawa: Bel-Studio, 2011), 216. Jak dowodzą badacze puścizny Ebnera, Buber znalazł inspirację u Ebnera; por. choćby Rivka Horvitz, „Ferdinand Ebner als Quelle von Martin Bubers Ich und Du”, w: Untersuchungen zum „, Brenner”, red. Walter Methlagl, Eberhard Sauermann, Sigurd Paul Scheichl (Salzburg: Otto Müller, 1981), 283-294; albo Jan Andrzej Kłoczowski, Filozofia dialogu (Poznań: W drodze, 2011), 45-46.

${ }^{5}$ Robert Spaemann, Osoby. O różnicy między czymś a kimś (Warszawa: Oficyna Naukowa, 2001), 9, 16. „To, kim jesteśmy” Spaemann wiąże z absolutną wyjątkowością funkcjonowania słowa “ja', a „to, czym jesteśmy” - ze zwykłą identyfikacją opierającą się na określeniach jakościowych i gatunkowych w sensie Arystotelesa. Te dwa rodzaje identyfikacji, z których pierwszy Spaemann nazywa identyfikacją numeryczną, a drugi można nazwać jakościową, są i muszą być komplementarne. Identyfikacja numeryczna zasadza się w pierwszej kolejności na funkcjonowaniu zaimków osobowych wraz z relacjami, które one nieodwołalnie wprowadzają 
Podsumowując, określenie człowieka jako istoty mówiącej (w pewnym przybliżeniu 'ja' to przecież nikt inny jak właśnie 'ktoś mówiący'), rzeczywiście różne kwestie rozstrzygając, moim zdaniem dopiero stawia właściwy problem człowieka jako problem otwierający szczególne, niespotykane w innych „rejonach bytu” trudności.

Piszę o tych trudnościach na wstępie, by uzmysłowić lub przypomnieć, na jak grząski grunt wchodzimy, próbując coś na tym polu przejaśnić. Podpisuję się jednakże pod stwierdzeniem Krzysztofa Skorulskiego, interpretującego Ebnera: „Jeśli rozjaśnimy słowo, rozjaśnimy człowieka [...]”6. Poniższy tekst jest próbą rozjaśnienia pewnych związków w dziedzinie spraw słowa, a więc i spraw człowieka.

\section{Zarysowanie problemu}

Przywołany Krzysztof Skorulski pisze o ciekawej prawidłowości:

Co jakiś czas [...] pojawia się w społeczeństwach problem rozziewu między stosowanymi słowami [...] a aktualnym życiem. Słowa wypowiadane z pewnych pozycji stają się puste, nic nie przekazują, nikogo nie poruszają [...]. Stają się pustosłowiem. [...] Nieprzypadkowo właśnie wtedy mamy do czynienia z obfitością rozważań o języku $[\ldots]^{7}$.

Wiek XX przyniósł doświadczenie totalitaryzmów, których sercem było coś więcej niż tylko wspomniana przez Skorulskiego nieprzystawalność: było

(są to relacje w obrębie sytuacji mowy), identyfikacja jakościowa z możliwością przypisania już jakoś danym „obiektom” określonych właściwości. Ta dwoistość ma swe źródło w najbardziej elementarnej właściwości mowy, wedle której zawsze mówimy o kimś/czymś coś. Spośród semantyków oprócz Bogusławskiego (por. A Study in the Linguistics-Philosophy Interface [Warszawa: Bel-Studio, 2007], 279-304) na nieredukowalny dualizm przejawiający się w koniecznym i ściśle uniwersalnym rozróżnieniu w języku tego, co odpowiada polskiemu rozróżnieniu 'ktoś' - 'coś', wskazywała Izabela Duraj-Nowosielska w: Robić coś i coś powodować. Opozycja agentywności i kazuatywności w języku polskim (Warszawa: Wydział Polonistyki UW, 2007), 93-132. Warto może dodać, że podobne kwestie nurtowały również buddyjskich teoretyków języka (co najmniej między V a XI w.); por. Bogusławski, Drzazgowska, Język w refleksji, t. I, 378-381, aczkolwiek nie widać u nich tak zasadniczego nacisku położonego na rozróżnienie 'ktoś' - 'coś', jaki jest widoczny np. u Spaemanna (tu są bliscy Wittgensteinowi).

${ }^{6}$ Krzysztof Skorulski, „Słowo i pustosłowie”, Przegląd Pedagogiczny 1 (2013): 105.

7 Tamże, 106. 
nim aktywne nadużywanie języka w różnych postaciach (wystarczy przypomnieć opatrzenie rozporządzeń w hitlerowskich Niemczech odpowiednimi „regułami językowymi”). Ogólny „rozziew” słów i życia zapewne stanowił grunt, na którym można było już aktywnie nadużywać mowy. Jednocześnie wiek XX przyniósł w filozofii i ogólnie w humanistyce ,zwrot lingwistyczny" (rozpoczęty już pod koniec XIX wieku), to jest dość powszechne uświadomienie sobie kluczowej roli mowy w życiu ludzkim ${ }^{8}$.

Wydaje się, że Skorulski trafnie mówi o społeczeństwach. Ta prawidłowość, o której pisze, dotyczyła bowiem także innych czasów i innych cywilizacji. Udokumentowana została sytuacja w starożytnych Chinach. Cywilizacja chińska odnotowała chyba najwcześniejszy w dziejach ,zwrot lingwistyczny", związany z narodzinami samej filozofii chińskiej: między V a III wiekiem przed Chrystusem. Sednem konfucjanizmu był w obliczu odczuwanego kryzysu społecznego projekt ,uporządkowania nazw”; badania semantyczne i logiczne chińskich filozofów (z różnych szkół) stymulowała myśl Konfucjusza o kluczowej roli mowy dla zdrowia społeczeństwa. Myśl ta zachowała się w następującym przekazie:

Jeśli nazwy nie są uporządkowane [poprawne, właściwe], mowa nie brzmi rozsądnie [błąka się]; jeśli mowa nie brzmi rozsądnie, spraw nie wieńczy sukces [rzeczy pozostają niewykonane]; jeśli spraw nie wieńczy sukces, obrzędy i muzyka nie kwitną; jeśli obrzędy i muzyka nie kwitną, kary nie pasują do zbrodni [kara jest nieznamienna]; jeśli kary nie pasują do zbrodni, ludzie nie wiedzą, do czego przyłożyć rękę i gdzie postawić nogę?

W przywołanych natomiast przez Skorulskiego latach osiemdziesiątych w Polsce Jan Józef Szczepański pisał podobnie:

Sprawa języka jest [...] sprawą podstawową. [...] Słowo, które przestaje pełnić [...] poznawcze funkcje, od którego przestajemy wymagać ustalania faktycznej prawdy, zaczyna nieuchronnie działać jako bakcyl rozkładu [...]. Język korum-

${ }^{8}$ Co nie znaczy, że przyniósł on powszechny rzeczywisty wgląd w mowy tej funkcjonowanie, choć pod wieloma względami sprawę przejaśnienia funkcjonowania mowy niewątpliwie posunął naprzód. Na temat oceny stanu badań nad językiem por. Bogusławski, Drzazgowska, Język w refleksji, t. II, 787-790.

${ }^{9}$ Cytuję za: Esa Itkonen, Universal History of Linguistics. India, China, Arabia, Europe (Amsterdam - Philadelphia: Benjamins, 1991), 90-91. W nawiasach kwadratowych podaję warianty przekładowe. Fragment można odnaleźć także w wydanych w Polsce Dialogach konfucjańskich (Wrocław: Ossolineum, 1976). 
powany nie może być narzędziem sumiennego działania, jest natomiast z reguły narzędziem manipulacji ${ }^{10}$.

W tychże latach osiemdziesiątych powstawała w wiadomych okolicznościach Józefa Tischnera Etyka solidarności, której trzeci rozdział traktuje o dialogu (w konkretnym kontekście tamtych czasów) ${ }^{11}$. Choć żaden z rozdziałów tej książki nie nosi tytułu „wolność” ani „prawda”, jest rzeczą wiadomą, że jedna i druga (pośród innych kwestii) Tischnera (wtedy i później) żywo zajmowały (obie w ich wielkiej złożoności, w różnych znaczeniach i uwikłaniach $)^{12}$. Obie na swoim najbardziej elementarnym poziomie są związane - i trudno znaleźć kogoś, kto chciałby te związki kwestionować $\mathrm{z}$ fenomenem dialogu, prościej: rozmowy.

W tym miejscu chciałabym zaproponować spojrzenie na relacje między dialogiem a wolnością i prawdą z perspektywy teorii języka i mowy. Poprowadzi nas ono z jednej strony do zrozumienia, dlaczego stała obecność dialogu jest symptomem zdrowia społecznego (jeśli nie jest z tym zdrowiem po prostu równoznaczna), z drugiej do wskazania na stosunek osoby (istoty mówiącej) do swej mowy, do prawdy i wolności jako na to, co buduje jej tożsamość.

Wspomniałam już na początku, że opowiadam się wraz z Konfucjuszem, Arystotelesem, Grzegorzem z Nyssy, Ebnerem, Buberem, Rosenzweigiem, Wittgensteinem, a także teoretykami tradycji bramińskiej w Indiach i pewnie

10 Jan Józef Szczepański, „Edukacja narodowa. Przemówienie wygłoszone na Zebraniu Ogólnym Towarzystwa Kursów Naukowych 14 czerwca 1980 r. w Warszawie" - cyt. za: Bogusławski, Roztrzasania, 203.

11 Józef Tischner, Etyka solidarności (Kraków: Znak, 2000), 17-20.

12 Por. choćby: „Język rzetelnego dialogu jest «językiem rzeczowym», a więc językiem, który «przystaje do rzeczy». To, co czarne, nazywa się czarnym, to, co białe, nazywa się białym. Nikt nie usiłuje robić rozkoszy z bólu”, tamże, 17. „W rzetelnym dialogu zawsze chodzi o prawdę”, tamże, 20. „Pytanie o prawdę jest pierwszym krokiem wolności, która żyje w świecie kłamstw. Nie bunt, nie protest, nie samobójstwo, lecz właśnie pytanie o prawdę. Kto w takim świecie zapytał o prawdę, już stał się wolny", Józef Tischner, Myśli o wolności, władzy i wspólnocie (Kraków: Znak, 2016), 13. „Wolność spełnia się wtedy, gdy kieruje się na zewnątrz samej siebie, ku jakiejś wartości, jakiemuś dobru, gdy je wybiera, urzeczywistnia. Ale co jest pierwszym dobrem wolności? Może chleb, życie, może miłość, może Bóg? Nie, pierwszym dobrem wolności jest prawda. [...] Im więcej między nami prawdy, tym więcej między nami wolności”, tamże, 11-12. „Nikt nie może przypisywać sobie monopolu na prawdę. Przekonanie to otwiera drogę do społeczeństwa dialogu". Józef Tischner, Etyka solidarności oraz Homo sovieticus (Kraków: Znak, 1992), 166. „[...] człowiek wita się z samym sobą. Uświadamia sobie swą wolność. [...] staje się podmiotem prawdy. [...] staje się własnością siebie”, tamże, 171. 
wielu innymi, za wskazaniem na mowę jako podstawową zdolność wyróżniającą człowieka. To wskazanie funduje w szczególności uznanie wtórnego w stosunku do mowy charakteru innych zjawisk ściśle ludzkich, wśród nich myślenia. Chcę twierdzić, że właśnie uznanie zależności myślenia od mowy wraz ze zrozumieniem fundamentalnej roli żywej, zwykłej, prowadzonej na poważnie rozmowy, to jest dialogu ${ }^{13}$, pośród rozmaitych zjawisk mowy pozwala zrozumieć, dlaczego jej stała obecność jest nierozerwalnie związana ze zdrowiem społecznym i jak funduje ona to, co trzeba nazwać tożsamością osobową. Zasadniczy nerw mój wywód zawdzięcza rozważaniom teoretycznojęzykowym Andrzeja Bogusławskiego ${ }^{14}$.

\section{Możliwość zaprzeczenia jako językowe źródło ludzkiej wolności}

Rzeczywistość mowy przedstawia sobą ogromną (rzec by można, nieprzebraną) rozmaitość zjawisk ${ }^{15}$. Systematyczne i satysfakcjonujące ich upo-

${ }^{13}$ Nie chcę tutaj robić różnicy między rozmową a dialogiem. Wydaje się, że w dość powszechnym odczuciu dialog jest czymś bardziej ,,podniosłym” i ,doniosłym” niż zwykła rozmowa (np. między mną a moim dzieckiem przy śniadaniu o tym, co dziś będziemy robić, albo w sklepie, kiedy płacę za zakupy, a kasjerka mnie pyta, czy mam drobne). Otóż właśnie tej różnicy świadomie nie robię. Te fundamentalne uwarunkowania, o których traktuję, w szczególności bardzo ważne w obecnym odniesieniu mówienie „na poważnie” czy też „na serio”, występują pierwotnie właśnie w zwykłych, najbanalniejszych rozmowach.

${ }^{14}$ Nie sposób wymienić wszystkich tekstów ważnych w obecnym odniesieniu. Ograniczę się do już przywołanych: Bogusławski, A Study; Bogusławski, Roztrząania, oraz Andrzej Bogusławski, Semantyka, pragmatyka. Leksykografa głos demarkacyjny (Warszawa: Takt, 2008).

15 Taką obserwację znajdujemy w szczególności u Wittgensteina: „Język potoczny stanowi część organizmu ludzkiego i jest nie mniej niż on skomplikowany [...] Ciche umowy co do rozumienia języka potocznego są niebywale skomplikowane", Wittgenstein, Tractatus, 20 [t. 4.002]. Kiedy mówię o rzeczywistości mowy, to mam na myśli wszystko, co mowę konstytuuje, nie czyniąc rozróżniania w szczególności na język i mówienie. Faktem jest, że wszystkie wartościowe teorie mowy (od chińskich moistów, gramatyków sanskryckich, Platona po Austina) za punkt wyjścia brały to, że język (słowa, wyrażenia, wyrazy) służy do mówienia. Nie chcę przez to powiedzieć, że rozróżnienie między językiem i mówieniem (Saussure'owskimi langue i parole) jest bezużyteczne czy wręcz nieadekwatne. Przeciwnie. Nie wolno jednak zapominać o właściwej hierarchii między nimi. Tu zgadzam się z Ebnerem, który nacisk kładł na prymat aktualnie wypowiadanych słów (Worte) w stosunku do wyrazów (Wörter). Nie zgadzam się jednak z jego twierdzeniem jakoby teoria języka (w tym logika) jako taka miała do czynienia tylko z tymi ostatnimi; por. Skorulski, „Słowo”, 107. 
rządkowanie jest kwestią ciągle otwartą, a w przekonaniu wielu zgoła niemożliwą i nawet niepotrzebną. W praktyce jednak pewne mniej lub bardziej systematyczne uporządkowania musimy przedsiębrać. Jednym z nich jest uporządkowanie wypowiedzi ze względu na funkcje ${ }^{16}$. Różni badacze wskazują na różne funkcje wypowiedzi, nikt jednak nie pomija jednej - funkcji poznawczej. Już natomiast nie wszyscy widzą ją jako funkcję podstawową. Nawet bez rozstrzygania tutaj tej kwestii trudno sobie wyobrazić mowę bez jej odniesienia do wiedzy. Trzeba zatem powtórzyć za Platonem: „Aby mówić o czymś, a nie tykać prawdy [...] na to nie ma żadnej prawdziwej sztuki i nigdy takiej nie będzie"17.

Tutaj wystarczy nam takie oto ostrożne sformułowanie: często mówimy coś po to, by się czegoś dowiedzieć lub kogoś o czymś poinformować; bez tego nie byłoby mowy ${ }^{18}$.

Zauważmy: chodzi tu o konieczność wpisania w mowę jedynie funkcji poznawczej, poznawczego celu wypowiedzi. Podstawowe uposażenie mowy w każdym poszczególnym przypadku pozostawia otwarta kwestię realizacji tej funkcji czy tego celu. To ważny punkt obecnego wywodu, można go sformułować następująco: mowa sama z siebie nie zawiera w sobie gwarantu, że w danej konkretnej sytuacji faktycznie zostaniemy poinformowani w sprawie, która nas interesuje. Tę (doskonale znaną niemal od początku refleksji językowej) zasadę podstawową osią wywodu uczynił Wittgenstein w Traktacie: Aby rozpoznać, czy obraz [w tym zdanie - E.D.] jest prawdzi-

${ }^{16}$ Współcześnie pojęcie funkcji języka (mowy) wiąże się przede wszystkim z nazwiskiem Karla Bühlera. W jego ujęciu funkcja poznawcza to Darstellungsfunktion - funkcja reprezentatywna. Por. Karl Bühler, Sprachtheorie (Jena: Gustav Fischer, 1934). Mitem jest jednak twierdzenie, jakoby Bühler w tym odniesieniu mówił coś, czego przed nim nie widziano. Przeciwnie, nawet w samej Europie już od starożytności przedsiębrano charakterystyki mowy według podobnych paramentów.

17 Platon, „Fajdros”, w: Platon, Dialogi (Warszawa: Unia Wydawnicza Verum, 1993), 49 [260E]. Oczywiście od razu podnosi się kwestia stosunku tego ,współtowarzyszenia” prawdy mowie do sytuacji ,życia w kłamstwie, manipulacji” (i akceptacji takiego życia) itd., jak to całkiem słusznie skonstatował w czasie Chojnickich Dni Tischnerowskich Krzysztof Wieczorek. Zgodnie z zapowiedzią, że interesować mnie będzie tutaj związek obecności dialogu ze zdrowiem społecznym, coś na ten temat będzie tu powiedziane - ogólnie jednak jest to kwestia wymagająca osobnej monografii.

${ }_{18}$ Taki punkt wyjścia moim zdaniem trzeba przyjąć i tylko takie powiedzenia nas tutaj będą interesować, czyli poza zasięgiem zainteresowania znajdą się, po pierwsze, wszystkie powiedzenia, które nie mają postaci oznajmującej, po drugie, pośród tych, które taką postać mają: wypowiedzi performatywne, definicje, fikcje (o nich będzie mowa osobno), sądy dotyczące wartości czy wreszcie formuły rachunków logicznych (por. też przypis 21). 
wy, czy fałszywy, trzeba go porównać z rzeczywistością. Z samego obrazu nie można rozpoznać, czy jest prawdziwy, czy fałszywy ${ }^{19}$.

Stąd wynika w dalszym rozrachunku, że do istoty powiedzenia należy możliwość zaprzeczenia mu. Wittgenstein tę możliwość powiązał z pojęciem sensowności wypowiedzi: tylko taka wypowiedź jest sensowna, którą można zanegować ${ }^{20}$. W ten sposób wyłączył z dziedziny sensu w szczególności zdania logiczne (tautologie i sprzeczności). W moim przekonaniu był to ruch, który odpowiadał Ebnerowskiemu stwierdzeniu, że tylko w dziedzinie zwykłej rozmowy mamy do czynienia $\mathrm{z}$ autentyczną prawdą $-\mathrm{u}$ Wittgensteina tylko zwykłe zdanie sensowne może być prawdziwe w pewnym ważnym znaczeniu ${ }^{21}$. Tak więc do istoty powiedzenia należy możliwość zaprzeczenia mu, a wraz z nim możliwość fałszu.

19 Wittgenstein, Tractatus, 11 [2.223]. Moim zdaniem konkluzywną argumentację dotyczącą konieczności utrzymania „korespondencyjnego” rozumienia prawdy (jakkolwiek skromnie ujętego), w szczególności niemożliwości utrzymania teorii „deflacjonistycznej”, przestawił Austin w artykule: John Langshaw Austin, „Truth”, w: Philosophical Papers (Oxford: Clarendon Press, 1961), 94-97. Trzeba jednak tutaj powiedzieć, że teorie języka i prawdy Austina i Wittgensteina różnią się w jednym kluczowym punkcie: Austin rezygnuje z odnalezienia czegoś innego niż czysta konwencja, co miałoby fundować stosunek między językiem i rzeczywistością, gdy tymczasem Wittgenstein na poziomie Traktatu wskazuje na ,tę samą różnorodność logiczną”, czyli „tę samą formę”, jako fundament odniesienia języka do rzeczywistości - ta „różnorodność/forma” nie jest jednak na elementarnym poziomie uchwytna słownie, ,ujawnia się” ona sama. To jest Wittgensteinowska odpowiedź na poszukiwanie takiego fundamentu także przez Platona i Ebnera. Ten ostatni mottem do swoich Fragmentów uczynił następujące zdanie z Fedona: „[...] nie możemy dopuścić, by kiedykolwiek powstała w duszy myśl, że w słowach nie ma oparcia” (Ebner, Słowo, 19). Wydaje się, że sam Platon uchylił się od sformułowania własnej odpowiedzi; Ebner natomiast szukał fundamentu, jak wielu przed nim (wraz z Platonem z Kratylosa), w etymologii.

${ }^{20}$ Ściśle rzecz biorąc, Wittgenstein mówi w Traktacie o zdaniach, nie o wypowiedziach czy powiedzeniach. Sprawa interpretacji pojęcia „zdanie” jest jedną z najtrudniejszych w dziejach myśli o języku. Nie ma tu miejsca na wchodzenie w szczegóły tych trudności. Ograniczę się zatem do konstatacji, że w moim pojęciu Wittgenstein tak używa terminu ,zdanie”, że może (a nawet musi) się on odnosić także do powiedzeń.

${ }^{21} \mathrm{~W}$ dziedzinie rachunków logicznych chodzi zdaniem Ebnera o coś innego, co nazwał Richtigkeit (Krzysztof Skorulski przekłada to wyrażenie jako 'poprawność', można by się zastanawiać nad 'prawidłowością' jako polskim odpowiednikiem). Podobne, nawet uderzająco podobne, w tym aspekcie stwierdzenia znajdujemy u Austina, który uważa, że prawdziwość/ fałszywość w sposób pierwotny przysługuje stwierdzeniom (nie zaś zdaniom jako abstrakcyjnym tworom językowym); por. Austin, „Truth”, 85-89, 92 („By była prawda potrzeba dwóch. Tak więc (oczywiście) nie może być żadnego kryterium w sensie cechy ukrytej w samym stwierdzeniu, która ujawniałaby, czy jest ono prawdziwe, czy fałszywe"). Na dalsze analogie 
Możliwość zaprzeczania i możliwość fałszu są z kolei ściśle związane $\mathrm{z}$ dwoma faktami: po pierwsze $\mathrm{z}$ istnieniem wielu referentów słowa „ktoś” i wielu obiektów, do których odnosi się słowo „coś”, którym przysługuje wiele różnych własności i stanów i z którymi dzieją się różne rzeczy; po drugie z naszym - jako mówiących - panowaniem nad alternatywami.

Pierwszy z tych faktów, istnienie wielości różnie uposażonych i uczestniczących w różnych zdarzeniach „ktosiów” i „cosiów”, został wydobyty już przez Platona w Sofiście jako warunek możliwości fałszu: w dyskusji Platona z Parmenidesem, głoszącym zasadniczą jedność bytu ${ }^{22}$. Platon w swoich zmaganiach z Parmenidesem, a były to także zmagania o poznawczą wartość mowy, którą Parmenides zanegował, doszedł do przekonania, że mowa do swojego prawidłowego funkcjonowania, takiego funkcjonowania, które „dotyka prawdy”, musi nieść ze sobą możliwość fałszu, a więc i wskazaną różnorodność rzeczywistości (mieszczącą w sobie jej zmiennośćc3). Innymi słowy, warunkiem zaufania mowie jako zasadniczo dobrze funkcjonującej także pod względem poznawczym jest zgoda na możliwość fałszu i różnorodność.

W nieco innym odniesieniu myśl o nieredukowalnej różnorodności rzeczywistości podtrzymał Arystoteles w Metafizyce: ,[...] gdyby wszystko było jednym, to nic nie byłoby naprawdę"24.

Przyjrzyjmy się teraz drugiej okoliczności, związanej z możliwością zaprzeczania i fałszu. Nazwałam ją wyżej panowaniem nad alternatywami. Otóż możliwość zaprzeczania jako istotowe uposażenie mowy w jej funkcji poznawczej trzeba widzieć jako korelat istnienia w strukturze wiedzy czegoś, co Bogusławski nazywa kontrastem kontradyktorycznym ${ }^{25}$. Najprościej rzecz ujmując: kiedy ktoś coś wie, to zawsze wie o kimś/czymś, że tak a tak,

między refleksją Ebnera i Austina wskazywał Krzysztof Skorulski w: „Aktualność i performatywność słowa", Paedagogia Christiana 1/35 (2015): 14-27.

22 Por. Platon, „Sofista”, w: Platon, Sofista. Polityk (Warszawa: PWN, 1956).

${ }^{23}$ Chcę tu więc nawiązać także, zgodnie z tradycją, do Heraklita (por. Hermann Diels, Walther Kranz, Die Fragmente der Vorsokratiker: griechisch und deutsch (Dublin, Zürich: Weidmann, 1972, 1973). Zmienność jednak, o którą tu chodzi, nie może być płynna, nie może być „totalnym” przechodzeniem wszystkiego we wszystko, „totalnym”, tzn. takim, które co do zasady uniemożliwia identyfikację w danym momencie, co jest czym (ewentualnie jakie) i co się stało.

${ }^{24}$ Cytuję za Janem Łukasiewiczem i w jego przekładzie: Jan Łukasiewicz, O zasadzie sprzeczności u Arystotelesa (Warszawa: PWN, 1987), 72. W Metafizyce znajdziemy ten fragment w miejscu 1007b.

${ }^{25}$ Por. np. Bogusławski, A Study, 125-132. 
nie (kontradyktorycznie) inaczej. Kiedy wiem, że kaszka dla mojego synka już ostygła, to wiem jednocześnie, że nie jest tak, iżby nadal była gorąca. Kiedy wiem, że ta kaszka stoi na stole, to wiem, że nie jest tak, iżby stała na kuchence (albo gdziekolwiek indziej). Własności, stany, relacje i zdarzenia są więc pierwotnie dane zawsze w kontrastach z (kontradyktorycznie) innymi własnościami, stanami, relacjami i zdarzeniami. Otóż my jako mówiący za sprawą wyrażeń, które nazywają własności, relacje, stany i zdarzenia (nie zaś tylko pierwotne obiekty wiedzy, tj. tych, o czym coś wiemy), mamy szczególny dostęp do nich, a co za tym idzie, do kontrastów, w których pozostają. Ten dostęp bierze się stąd, że możemy o nich mówić, a więc i docelowo coś wiedzieć - nie jest to dane np. zwierzętom. W szczególności, możemy wiedzieć, że choć coś jest tak, a nie inaczej, mogłoby być inaczej. To właśnie - za Bogusławskim - nazywam naszym panowaniem nad alternatywami ${ }^{26} \mathrm{i}$ wiążę z możliwością zaprzeczania, która nas tutaj zajmuje.

Nietrudno wreszcie zauważyć, że ta ostatnia zdolność, to ludzkie panowanie nad alternatywami leży u podstaw wolności jako możliwości wyboru. Zawsze bowiem jest nam jako mówiącym w odniesieniu do każdego przedmiotu i każdej osoby dana jednocześnie obok aktualnych własności, stanów, relacji i zdarzeń wielość potencjalnych własności, stanów, relacji i zdarzeń. Ludzie zaś - trudno się z tą prostą konstatacją nie zgodzić - to także istoty coś robiące. Dzięki mowie możemy coś robić z alternatywami, w szczególności spośród nich wybierać.

Związek wolności z zaprzeczaniem był po tysiąckroć konstatowany, w tym sensie jest czymś banalnym. Zgodnie z intuicją Józefa Tischnera, jakkolwiek podstawowy, nie on jednak wskazuje na to, o co w wolności przede wszystkim chodzi: chodzi w niej jego zdaniem o stosunek osoby do praw$\mathrm{dy}^{27}$. Będę się starała tę intuicję analitycznie rozwinąć.

\section{4. „Rdzeń mowy"28}

Możliwość fałszu, istotowo powiązana z brakiem w samej mowie w każdym poszczególnym przypadku gwarantu jej prawdziwości, nie jest „całą prawdą" o podstawowej konstytucji mowy w jej funkcji poznawczej. Już

${ }_{26}$ Por. np. Bogusławski, Drzazgowska, Język w refleksji, t. II, 787.

27 Tischner, Myśli, 10-12.

${ }^{28}$ Bogusławski mówi o opisanych niżej sytuacjach jako o „rdzeniu mowy”. Por. Bogusławski, Semantyka, 44-56. 
samo wskazanie na prawdę i wiedzę jako cel mowy sugeruje, że między prawdą a fałszem nie ma w tym odniesieniu symetrii. Otóż mowa nie mogłaby funkcjonować tak, jak funkcjonuje, gdyby prawda rzeczywiście nie była gdzieś realizowana w sposób, w którym uczestniczyłyby co najmniej dwie osoby. To uczestnictwo w prawdzie to nic innego jak zwerbalizowana lub możliwa do zwerbalizowania wiedza. By rzecz sformułować wyraźnie: chodzi o taką sytuację, w której na poważnie mówię, że tak-a-tak, wiedząc, że tak właśnie jest, a mój adresat również wie, że ja wiem, że tak jest - to znaczy wie, że mówię prawdę - i jest gotów to stwierdzić (lub przynajmniej jakoś potwierdzić, choćby niewerbalnie). Kiedy podaję mojemu dziecku kaszkę i mówię „Kaszka dla ciebie”, to ono wie, że ja wiem, że to jest kaszka (nie mleko, nie sok, nie woda) dla niego (nie dla kogokolwiek innego) potwierdzeniem tego w przypadku dziecka jest sięgnięcie bez wahania po butelkę i picie. Ważną rzeczą, którą tutaj trzeba jeszcze odnotować, jest latentna obecność kontrastów, to jest alternatywnych możliwości. Ta obecność stanowi o świadomości i sprawia, że cała rzecz - w zgodzie z tym, co przedstawiłam wyżej - jest ufundowana na wolności.

Bardzo ważnym ograniczeniem tej sytuacji jest wskazanie, że musi się ona realizować gdzieś. Innymi słowy, chodzi o to, że nie potrafimy w sposób ogólny i efektywny (przez podanie jakiejś jednoznacznej charakterystyki) wskazać, gdzie mianowicie się ona realizuje ${ }^{29}$. Jest to znów ściśle skorelowane $\mathrm{z}$ brakiem ogólnego kryterium prawdy w samym zdaniu, na które taki nacisk kładli Wittgenstein i Austin, a pośrednio także Ebner, wskazując mianowicie, że prawda może się „wydarzyć” tylko między ,ja” i „ty”. Jest to również skorelowane $\mathrm{z}$ inherentnym brakiem możliwości przeprowadzenia dowodu tego, że ktoś coś faktycznie wie. Nie zmienia to znów faktu, że w konkretnych przypadkach rzeczywiście mamy świadomość, że ktoś inny wie, że jest tak, jak mówi.

\section{Potrzeba prawdy i obowiązek prawdomówności}

Obok dwóch wskazanych wymiarów: koniecznego istnienia możliwości fałszu i zaprzeczania oraz koniecznych przypadków wspólnego, wolnego

${ }^{29}$ Wydawać by się mogło, że takim naturalnym miejscem realizacji prawdy mogłyby być rozmowy rodziców z dziećmi (jako coś pierwotnego w sensie opanowania języka). Nie ma jednak żadnej konieczności, by tak było. Natomiast skutki zbyt częstej nieobecności uświadomionej przez obie strony prawdy w rozmowach z dziećmi mają z całą pewnością negatywny 
uczestnictwa w prawdzie jest jeszcze jeden w tym miejscu istotny wymiar relacji między mową a prawdą i wolnością.

Mówiłam już o tym, że między prawdą i fałszem nie ma symetrii, na co wskazuje fakt, że z tej dwójki w sensie ogólnym to prawda jest celem mowy $^{30}$. Z innej perspektywy możemy powiedzieć, że tylko prawda (nie zaś fałsz) jest cenna. Także w tym praktycznym aspekcie, że stanowi ona jedyny solidny fundament skutecznego działania. Niezwykle dobitnie przedstawiał ten aspekt sprawy Platon w początkowych partiach Kratylosa (zbijając w szczególności relatywizm Protagorasa): gdybyśmy działali zależnie od „skoków naszej wyobraźni”, nie zaś zgodnie ze stosowna wiedza, to nasze działania miałyby co najmniej nikłą skutecznośćc ${ }^{31}$. Nie znaczy to, że możemy definiować prawdę w terminach użyteczności.

Tak więc z jednej strony zależy nam na prawdzie, a z drugiej strony nie dysponując żadnym ogólnym gwarantem prawdziwości wypowiedzi, jako istoty o skończonych możliwościach nie jesteśmy w stanie za każdym razem przedsiębrać osobnej konfrontacji z rzeczywistością (jakkolwiek czasem jest to możliwe). Choć więc wiemy, że prawda gdzieś musi być efektywnie realizowana, i nawet możemy wiedzieć, że właśnie w wielu naszych rozmowach się ona zrealizowała, w sposób ogólny możemy scharakteryzować nasze do niej odniesienie w mowie innych następująco: jesteśmy tutaj na tych innych zdani. Prawda jako wartość, potrzeba (u Simone Weil ,świętsza od wszystkich innych potrzeb" "32) ukazuje w ten sposób w relacji do nas jako mówiących swoje oblicze „,biedy”, „niedostatku”: jesteśmy w odniesieniu do prawdy „potrzebującymi”. Łatwo zauważyć, że jeśli odwrócimy tę relację, to inni okażą się często w odniesieniu do prawdy zdani na nas.

Obok potrzeby prawdy istnieje obowiązek mówienia prawdy. Wydawać by się mogło, że jest on w szczególny sposób związany z rozpoznaniem potrzeby prawdy. Ten wątek był ważny u Tischnera. Twierdził on, że pytanie jest „wezwaniem do odpowiedzi”, „wezwaniem do nieokłamywania”, ,we-

wpływ nie tylko na opanowanie języka. W poruszający sposób pisze o wpływie „,autentycznego” słowa na rozwój dziecka Chapel; por. Joseph F. Chapel, „Ferdinand Ebner: na początku było słowo", Paedagogia Christiana 1/35 (2015): 99-109.

${ }^{30}$ Moim celem, owszem, może być podsunięcie komuś jakiegoś fałszu, ale zasadniczo ja sam nie chciałbym, by mnie ktoś podsunął fałsz jako prawdę. Samo ,przebranie” fałszu w „szaty” prawdy wiele mówi o wartości tej ostatniej. Wskazywał na to wielokrotnie m.in. Tischner.

31 Platon, Kratylos (Lublin: KUL, 1990), 386d-388c.

32 Simone Weil, Zakorzenienie i inne fragmenty. Wybór pism (Kraków: Znak, 1961), 193. 
zwaniem bezwzględnym" 33 . Powstaje pytanie, na czym się ta „bezwzględność", o której pisze Tischner, zasadza. Czy na samym tylko rozpoznaniu potrzeby? Jak dobrze wiadomo, obowiązek jest czymś zasadniczo różnym od konieczności fizycznej w tym elementarnym sensie, że choć wskazuje wektor działania, to go nie zniewala, nie determinuje. Działanie podążające za Tischnerowskim „wezwaniem”, to jest prawdziwa odpowiedź na pytanie, musi być odpowiedzią wolną, a to znaczy w świetle powyższej charakterystyki: jest odpowiedzią, która w tle ma świadomość różnych możliwości reakcji.

Czy jednak to nasze (przynajmniej częściowe) zdanie na siebie nawzajem w odniesieniu do potrzeby prawdy i (bezwzględny w ujęciu Tischnera) obowiązek prawdomówności mają jakiś korzeń w samej sytuacji mowy? Czy, innymi słowy, obowiązek prawdomówności zasadza się tylko na rozpoznaniu potrzeby? Czy nie ma żadnego innego fundamentu, na którym mógłby się oprzeć? Sądzę, że taki fundament całkiem jasno odsłania sytuacja dialogu.

\section{Dialog jako możliwość zaprzeczenia w horyzoncie prawdy. Powaga}

Wszystkie te momenty: prawda jako cel i potrzeba, odpowiadający im obowiązek prawdomówności oraz możliwość zaprzeczania i fałszu wraz z założoną różnorodnością mówiących, przedmiotów mowy i askrypcji, kontrastem kontradyktorycznym i naszym szczególnym do niego dostępem fundującym świadomość i wolność, są istotowo obecne w każdej zwykłej sytuacji rozmowy, to znaczy dialogu.

Oto charakterystyka dialogu w ujęciu Bogusławskiego:

Jeśli zechcemy znaleźć $\mathrm{w}[\ldots]$ mowie wyróżniony element, w którego normalnym działaniu $[\ldots]$ tkwi to, co konstytutywne dla mówienia $[\ldots]$ w jego logicznie pierwotnych realizacjach, to [...] musimy zatrzymać się na negacji. Aktualne tworzenie zdań na poważnie to zawsze wybór między użyciem a nieużyciem negacji $[\ldots]$. Chodzi o wybór dotyczący negacji robiony na serio, tzn.

${ }^{33}$ Rzecz była przedmiotem namysłu w trakcie sesji „Józefa Tischnera refleksja nad życiem publicznym”. Materiały z niej są zawarte w tomie „Bąźz wolność Twoja”: Józefa Tischnera refleksja nad życiem publicznym, red. Jarosław Jagiełł, Władysław Zuziak (Kraków: Znak i PAT, 2005). 
zgodnie z jej naturą, urodą. To samo odnosi się do odbioru zdań. Aktualnemu wprowadzeniu negacji lub odrzuceniu jej (twierdzeniu) odpowiada analogiczne aktywne nastawienie negacyjne w odbiorze. Tak właśnie tworzy się dialog jako zasadnicza forma bytowania języka ${ }^{34}$ [podkreślenia ED].

Trzeba jasno stwierdzić, że Bogusławskiemu nie chodzi tutaj o samą obecność lub nieobecność słowa „nie” i innych pokrewnych. Te czysto powierzchniowe zjawiska trzeba odróżnić od ,autentycznego operowania negacją”. Bez tego operowania, bez Ebnerowskiego „słowa jako czynu”, wyraz „nie” nie miałby żadnego znaczenia ${ }^{35}$. Co to jednak znaczy?

Po pierwsze, autentyczne operowanie negacją zakłada rozumienie konsekwencji użycia lub nieużycia negacji w danym kontekście, czyli określoną wiedzę semantyczną, która oparta jest na kontrastach ${ }^{36}$. Najczęściej jest to wiedza nieświadoma, ale realizowana w praktyce (tzn. w praktyce każdy doskonale rozumie różnicę razem z jej konsekwencjami między powiedzeniem „Jaś był wczoraj w szkole” a „Jaś nie był wczoraj w szkole”, między „Kupiłam [jak zawsze] cortlandy” a „Kupiłam inne jabłka [nie cortlandy]”).

Po drugie, ,autentyczne operowanie negacjąa” oznacza możliwość i gotowość do aktywnego przeciwstawienia się czyjemuś powiedzeniu. Pamiętamy: wszystko to się dzieje w horyzoncie świadomości, że prawda jest cenna. Aktywne przeciwstawienie się więc to oprócz prostego wyrażenia niezgody (które przecież też jest Ebnerowskim i Austinowskim aktem) niepodejmowanie działań niezgodnych z głoszonymi treściami - w ostatecznym zaś rozrachunku postawienie swojego życia na szali po jednej ze stron opozycji, kontrastu (tak czytam Kafkowskie utożsamienie „Słowo to wybór między życiem i śmiercią").

Jak pamiętamy, mowa sama z siebie nie może zagwarantować swojej prawdziwości. Jeśli więc nie ma sposobu na dostępną wszystkim zainteresowanym konfrontację z rzeczywistością, to tę gwarancję może dać tylko mówiący - samym sobą, to znaczy swoją osobą. I rzeczywiście, w zwykłej (ele-

34 Bogusławski, Roztrząsania, 213.

${ }^{35}$ W tym sensie rację mają wszyscy ci, którzy kładą nacisk na to, że wyrażenia nie mają znaczenia poza użyciem, tj. między innymi Wittgenstein (także wczesny) i Peirce.

${ }^{36}$ Czy też na sprzecznościach albo, jak chciał de Saussure, na opozycjach, albo, jak chcieli logicy buddyjscy, na wykluczeniach - wszystko to warianty wysłowień tego samego (por. Bogusławski, Drzazgowska, Język w refleksji, t. I, 227-240, 378-382). Ta wiedza semantyczna jest nieoddzielalna od tego, co funduje logikę (w sensie rachunków). Trudno myśleć o dialogu bez jej uwzględnienia. Dlatego atak Ebnera na logikę (jako to, w czym słowo jest oderwane od kontekstu swojego życia) nie jest, w moim pojęciu, słuszny. 
mentarnej albo bazowej, tzn. takiej, w której nie ma żadnych zrozumiałych dla zainteresowanych sygnałów, że jest inaczej) sytuacji mowy sam mówiący staje za swoim powiedzeniem, soba gwarantując jego prawdziwość. Czasem ta gwarancja jest werbalizowana (gdy ktoś mówi, że ręczy za to, co mówi), najczęściej pozostaje niewypowiedziana. Na ten stan rzeczy wskazuje łacińska etymologia assertio ['stwierdzenie']: stwierdzając coś (mówiąc coś na poważnie), niejako „przywiązuję” siebie do tego mojego stwierdzenia. Taką analizę prawdomówności przedstawiał w szczególności Peirce ${ }^{37}$. Wyjaśniał on, że jeśli coś mówię na poważnie, to nakładam na siebie zobowiązanie do działania w przyszłości zgodnego (niesprzecznego ${ }^{38}$ ) z tym moim obecnym powiedzeniem. Znaczy to, że mówiąc coś na serio, ręczę swoją osobą za to, co mówię, czyli zobowiązuję się działać zgodnie z tym, co mówię. Jeśli ty mówisz poważnie, zobowiązujesz się do podobnej zgodności.

Autentyczny dialog, autentyczna rozmowa jest ufundowana na tych zależnościach: wzajemna zgoda lub niezgoda muszą dokonać się w pełnym nieskrępowaniu, tak by mówiący swobodnie (ale przecież niearbitralnie) i świadomie mogli wybrać między „tak” i „nie” - bo wybierając między innymi decydują, na jakie działania samym sobie dają przyzwolenie i do czego się zobowiązują. W ten sposób zaś - we wzajemnej relacji w horyzoncie prawdy i w pełnym wobec niej i wobec siebie nawzajem nieskrępowaniu budują swoją tożsamość jako osób. Wszystko to współbrzmi z Martina Bubera stwierdzeniem, że poza mową jesteśmy jako osoby „unicestwieni”39.

Być może tutaj leży źródło przekonania o istnieniu związku między prawdą a powinnością. Być może tutaj jest również miejsce Ebnerowskiej

${ }^{37}$ Por. Charles Sanders Peirce, Semiotische Schriften, Bd. 1 (Frankfurt am Main: Suhrkamp, 1986), 411; Charles Sanders Peirce, Semiotische Schriften, Bd. 2 (Frankfurt am Main: Suhrkamp, 1990), 398; Charles Sanders Peirce, Phänomen und Logik der Zeichen (Frankfurt am Main: Suhrkamp, 1983), 75.

38 Właśnie w tym miejscu ma szczególne znaczenie udział wiedzy semantycznej, zasadzającej się na sprzecznościach czy też kontrastach.

39 Cyt. za: Bogusławski, Roztrząsania, 216. Współbrzmi to również z Ebnerowskim ujęciem prawdy jako adekwatności wypowiedzi i osobowości. Skorulski pisze, interpretując Ebnera: „Wypowiedź musi «mieć pokrycie» w osobowości, czyli wypowiadając się, muszę swoim życiem podtrzymywać to, co mówię”, przy czym „wiem, że mam możliwość, by tego nie podtrzymywać”, Skorulski, „Słowo”, 111. Jak wiadomo, Ebner nawiązywał w ten sposób do Kierkegaarda i jego koncepcji „reduplikacji”, tj. integracji słowa i życia (w sposób pełny dokonała się ona w Jezusie); por. Krzysztof Skorulski, „Ebnerowska dialogika w kontekście”, w: Ebner, Stowo, 266, 290. W podobnym duchu wypowiadał się Tadeusz Styczeń, „Aksjologiczne podstawy kultury politycznej”, w: Sacrum i kultura. Chrześcijańskie korzenie przyszłości, red. Ryszard Rubinkiewicz, Stanisław Zięba (Lublin: KUL, 2000), 174-175. 
miłości jako otwartości na drugiego, która ma być kluczem do rozumienia mowy ${ }^{40}$. Ta otwartość w świetle powyższych rozważań byłaby w szczególności „zrobieniem drugiemu miejsca” na jego odniesienie do prawdy, prawdy, która - choć wspólna, jak mowa - wymaga osobistego odniesienia ${ }^{41}$.

Wszystko to rzuca dodatkowe światło na podstawową cechę mowy w jej funkcji poznawczej. Otóż do czynienia z tą funkcją możemy mieć tylko wtedy, kiedy mówimy na poważnie. Na ten moment i jego związek z mówieniem w horyzoncie prawdy kładł szczególny nacisk, obok Ebnera, Frege ${ }^{42}$.

\section{Mowa a myślenie}

Wydaje się jasne, że tak przedstawiona, jak wyżej, mowa to nie tylko czysto zewnętrzne wybrzmiewanie zdań. Stanowi ona przede wszystkim nośnik sensu. Sens jest, jak pisałam, źródłowo związany z możliwością zaprzeczania, tj. możliwością aktywnego przeciwstawiania się (lub aktywnej zgody, skoro chodzi o możliwość). Dla ujawniającej takie swoje oblicze mowy ucho to tylko pośrednik: właściwą władzą odbioru jest stuchający rozum. Zarysowany moment egzystencjalny, moment osobistej poręki w horyzoncie prawdy pokazał wyraźnie, że nie jest to rozum czysto teoretyczny, lecz niepodzielny rozum, by tak rzec, teoretyczno-praktyczny. W tym odniesieniu trzeba pełną rację przyznać Ebnerowi (i Ojcom Kościoła, a także Hamannowi).

W tak rozumianej mowie bowiem ,teoria”, to jest semantyczna wiedza o kontrastach (a więc także o alternatywach), jest nierozerwalnie związana z praktyką, to jest z naszą poręką płynącą z powagi oraz towarzyszącym jej

40 Ferdinand Ebner, Wort und Liebe (Berlin: LitVerlag, 2015), 44-45.

${ }^{41}$ O niezbywalności osobistego poznawczego stosunku do (,transsubiektywnej”) prawdy i jej związku z „zasadą dialogu” pisał m.in. Tadeusz Styczeń; por. Styczeń, „Aksjologiczne podstawy", 179. Trzeba zaznaczyć, że posługiwał się on szerszym rozumieniem prawdy, wedle którego może ona dotyczyć także tzw. sądów aksjologicznych. Jego konstatacje można jednak z powodzeniem przenieść na rozpatrywaną tutaj przeze mnie prostszą sytuację stwierdzeń czysto deskryptywnych (tacy myśliciele jak Ebner czy Kierkegaard myśleli o tych rzeczach zapewne łącznie). Kwestia systematycznego włączenia sądów (stwierdzeń) aksjologicznych w moje obecne rozważania jest bezspornie ważna, choć trudna. Wymaga ona osobnego potraktowania.

42 Por. Gottlob Frege, „Myśl. Studium logiczne”, w: Gottlob Frege, Pisma semantyczne (Warszawa: PWN, 1977), 100-129. Tu znów trzeba stwierdzić, że rozziew między dialogiką a analitycznym podejściem do mowy nie jest tak radykalny, jakim chciał go mieć Ebner. 
zobowiązaniem do działania w zgodzie z tym, co mówimy. Właśnie jako taka mowa formuje myślenie.

Sądzę, że zarysowana przeze mnie charakterystyka mowy jest podstawą intuicji Hannah Arendt, wyrażonej w tezie o banalności zła, zła, które u swych podstaw ma chorobę społeczną ${ }^{43}$, objawiającą się brakiem autentycznego dialogu czy też, jak chce Krzysztof Skorulski, ,rozziewem między słowami i życiem". Jest to doskonale widoczne w następującym fragmencie (o Eichmannie):

[...] język urzędniczy stał się jego językiem, ponieważ [...] nie był on w stanie wypowiedzieć ani jednego zdania, które nie byłoby kliszą [...] wszystko, co mówił, było „pustosłowiem” [które nie kryło żadnych myśli]. [...] Eichmann mimo swojej dość słabej pamięci powtarzał słowo po słowie te same sztywne frazy i wymyślone przez siebie klisze (kiedy udało mu się samodzielnie skonstruować zdanie, powtarzał je dopóty, dopóki się nie stało kliszą) [...]. Bez względu na to, do kogo mówił albo pisał, to, co mówił, było zawsze takie samo, wyrażone tymi samymi słowami. Im dłużej się go słuchało, tym oczywistszym się stawało, że jego niezdolność mówienia była ściśle związana z niezdolnością myślenia, mianowicie, myślenia z punktu widzenia kogoś innego. Komunikacja z nim była niemożliwa nie dlatego, że kłamał, lecz dlatego że był otoczony najsolidniejszą ze wszystkich ochroną przed słowami i obecnością innych, a więc także przed rzeczywistością jako taką ${ }^{44}$.

Niezdolność mówienia / myślenia przypisana Eichmannowi przez Arendt polegała na „sztywnym” powtarzaniu tego samego niezależnie od sytuacji i rozmówców, a w dalszym rozrachunku na niezdolności przyjęcia perspektywy kogoś innego. Przyjęcie perspektywy innego ma swoje źródło w sytuacji rozmowy, która po pierwsze zakłada zamianę ról ${ }^{45}$, po drugie, jak próbowa-

43 „Ma u swych podstaw” nie znaczy ,jest całkowicie zdeterminowane przez” - nie ma tu związku koniecznego. Inaczej zabrakłoby miejsca na odpowiedzialność.

${ }^{44}$ Hannah Arendt, Eichmann in Jerusalem (New York: Penguin Books, 1983), 49.

${ }^{45}$ O tym przyjmowaniu perspektywy innego w szczególności w odniesieniu do możliwości znalezienia prawdy o sobie i roli dialogu na tej drodze pisał Tischner w Etyce solidarności: ,[...] ani ja, ani ty nie jesteśmy w stanie poznać prawdy o sobie, jeśli pozostaniemy w oddaleniu od siebie [...], lecz musimy spojrzeć na siebie niejako z zewnątrz, ja twoimi, a ty moimi oczami, musimy porównać w rozmowie nasze widoki [...] gdy ja patrzę na ciebie i biorę pod uwagę tylko to, co sam widzę, i gdy ty patrzysz na mnie i uwzględniasz tylko to, co widzisz - obydwaj ulegamy częściowemu złudzeniu", Tischner, Etyka solidarności, 18. Prawda o sobie to kwestia bardziej szczegółowa niż ta, której dotyczy obecny artykuł, choć niewątpliwie z jego tematyką 
łam pokazać, zakłada gotowość do świadomego i swobodnego (choć niearbitralnego) przyjęcia lub odrzucenia słowa drugiego - przyjęcia lub odrzucenia, które w oczywisty sposób zakłada, że rozumiemy to, co jest powiedziane, i za którym stawiamy naszą osobę. To rozumienie ufundowane jest na naszym wspólnym uczestnictwie w słowie.

Jak już kilkakrotnie za Ebnerem i Austinem wskazywałam, prawda inherentnie związana z mową, by być tym, czym jest (niezależnie od tego, że na elementarnym poziomie każdy musi się do niej odnieść osobiście), musi móc należeć co najmniej do dwojga (ostatecznie: do wielu). Zamknięcie się w kręgu własnego życia wewnętrznego (Ebnerowska samotność ,ja”) jest niczym innym jak zamknięciem się na prawdę. Dlaczego sztywno powtarzane frazy (zauważmy: nie słowa) tak znakomicie nadają się, by dokonać takiego zamknięcia? Bo udając słowa, tworzą pozór „otwarcia”, „bycia w kontakcie" (że jest to pozór i jako taki jest on odbierany, dowodzą wielokrotnie zadawane te same pytania - pomimo ,udzielonej odpowiedzi”; rzecz w tym, że „udzielona odpowiedź” nie jest odpowiedzią). Czego im jednak brak, by były autentycznymi słowami? Wszystkiego tego, o czym pisałam, co jednak przejawia się w jeszcze jeden wyżej niewydobyty sposób.

Rzeczywistość, którą prawda naszych wypowiedzi ma oddawać, ma w swych fundamentach zgodnie z tym, co mówił Heraklit, naturę zdarzeniową (z naszej perspektywy: działaniową). Proszę w szczególności zauważyć, że taka jej natura - wbrew temu, jak Heraklita zinterpretowano - nie wyklucza możliwości jej ujęcia w mowie. Można powiedzieć nawet więcej: jako warunek różnorodności jest dla prawidłowego funkcjonowania mowy konieczna. Jest to ściśle skorelowane $\mathrm{z}$ tą doskonale przez wybitnych teoretyków mowy widzianą jej cechą: przeznaczeniem do wyrażania nowego. Widział tę cechę Michaił Bachtin ${ }^{46}$. Wittgenstein pisał tak: „Leży w istocie zdania, że może nam ono przekazać nowy sens. [...] musi [ono] przekazywać nowy sens za pomocą starych wyrażeń. Zdanie powiadamia nas o pew-

bardzo ściśle związana. Na tym polu - jak słusznie zauważył w czasie Chojnickich Dni Tischnerowskich Krzysztof Wieczorek - poszukiwanie prawdy rodzi szczególne trudności (może nawet pojawić się wątpliwość, czy prawda o sobie w ogóle jest przedmiotem poszukiwań).

${ }^{46}$ Michaił Bachtin, „Problem gatunków mowy”, w: Michaił Bachtin, Estetyka twórczości słownej (Warszawa: PIW, 1986), 348-402. Warto tutaj przytoczyć fragment tego ważnego także w obecnym związku tekstu: ,[...] słuchacz odbierając i rozumiejąc [...] znaczenie mowy, jednocześnie zajmuje wobec niej aktywną pozycję współodpowiadającą: zgadza się z tą mową lub nie zgadza się (całkowicie lub po części), uzupełnia ją i przekształca, sposobi się do jej wypełnienia [...]", tamże, 359 . 
nej sytuacji”47 [4.027, 4.03]. Buber zaś pisał tak (zupełnie w zgodzie z Heraklitem):

Pomimo wszelkich podobieństw każda żywa sytuacja ma - niczym nowo narodzone dziecko - nowe oblicze, jakiego nigdy dotąd nie było na świecie i nigdy więcej nie będzie. Domaga się od ciebie reakcji, której nie da się zawczasu przygotować. Nie domaga się żadnej z rzeczy minionych. Domaga się natomiast autentycznej obecności, odpowiedzialności; domaga się ciebie ${ }^{48}$.

Nie jestem tu w stanie przedstawić systematycznej analizy uwarunkowań społecznych, które mogą skłaniać (ale nie: determinować) jednostki do rezygnacji z bycia autentycznymi podmiotami dialogu. Takie analizy, mniej lub bardziej systematyczne, były zresztą nieraz prezentowane. Ich włączenie w kontekst obecnych rozważań byłoby rzeczą ciekawą, zdecydowanie jednak przekraczającą ramy artykułu.

Naszkicowany obraz funkcjonowania mowy w jej aspekcie poznawczym oraz naszych zanurzonych w mowę działań, ukazujący w szczególności stosunek momentów prawdy i wolności, jest próbą wyjaśnienia, na jakich fundamentach opierać się musi mowa, by sprostać wymogom wyrażania nowego sensu i autentycznej przytomnej reakcji na coraz to nowe sytuacje, wymogom, które czynią z nas podmioty, żyjące w zdrowej wspólnocie.

\section{Podsumowanie: dialog i budowanie tożsamości}

Człowiek jako istota mówiąca - jest to rzecz w sumie znów nienowa stanowi sam dla siebie zadanie. Jest to zadanie, do którego trzeba zgodnie z tradycją odnieść określenie „egzystencjalne”, dotyczy ono bowiem właśnie człowieka w całości i w odniesieniu do jego własnego życia. Rzecz jednak w tym, że sama ta całość jest zawsze dopiero zadana. Dlatego z sensem można mówić właśnie o „budowaniu tożsamości”. Bo jest to zawsze zadanie, a nigdy coś danego ${ }^{49}$. Dlatego też można powiedzieć, posługując się formułą

47 Wittgenstein, Tractatus, 23 [t. 4.027, 4.03].

${ }^{48}$ Cyt. za: Marshall B. Rosenberg, Porozumienie bez przemocy. Ojęzyku serca (Warszawa: Czarna Owca, 2015), 106.

49 Jedną z osi swojego projektu filozofii pierwszej jako filozofii czynu pojęcia „tego, co dane" i ,tego, co zadane” uczynił Bachtin. Por. Michaił Bachtin, W strone filozofii czynu (Gdańsk: słowo/obraz terytoria, 1997). 
Wittgensteina, że ciągle narzucające się pytanie o to, kto to jest człowiek, w ogóle i ten konkretny, nie ma sensu (por. „Naprawdę, jaka jesteś nie wie nikt, bo nie wiesz tego nawet sama ty" - Janusz Kofta). By odwołać się do obrazu: z naszą tożsamością rzecz ma się tak jak ze statkiem, którym jednocześnie żeglujemy i który budujemy. Porównanie to ma - oprócz innych - to niedomaganie, że w przypadku naszej tożsamości sama żegluga jest budowaniem. Trzeba powiedzieć, że znajdujemy się w dość karkołomnej sytuacji.

Kluczowym momentem budowania tożsamości jest fakt posiadania mowy. Próbowałam pokazać, w jaki sposób zakorzenione są w nim wzajemnie powiązane ze sobą prawda i wolność - dwie rzeczy, których, jeśli je brać $\mathrm{w}$ ich podstawowym znaczeniu, nie znajdziemy w świecie pozaludzkim. Każdorazowe odniesienie danej osoby do prawdy w wolności wobec drugiej osoby $w$ dialogu, czyli „,przywiazanie” siebie do tego, co jest powiedziane, stanowi samo serce mowy i jednocześnie teoretyczno-praktyczny moment, który wraz z innymi konstytuuje proces budowania tożsamości - przynajmniej w jakimś jego aspekcie ${ }^{50}$. Jest tak dlatego, że kiedy coś mówimy na poważnie, stajemy się niejako zakładnikami tego, co mówimy, sami na siebie, to jest na własne działania, nakładamy określone ograniczenia - ograniczenia zgodności naszych działań z tym, co mówimy. Te ograniczenia nie mają żadnej zewnętrznej sankcji. Jedyną sankcją jest nasza własna integralność - w tym sensie mówienie nieprawdy jest zadawaniem (oczywiście niecielesnej) rany samemu sobie.

Wszystko to brzmi dość ponuro, a nasza sytuacja - dokładnie tak jak chciał Tischner - wydaje się dramatyczna. I rzeczywiście taka jest. Trzeba wszakże pamiętać o jednej rzeczy: mówienie prawdy, otwartość na prawdę i działania zgodne z prawdą, choć bywają trudne, nie są ostatecznie krępujące, wręcz przeciwnie. Paradoksalnie: zgoda na ograniczenie przez prawdę jest $\mathrm{w}$ istocie tym, co wyzwala, rodzi nieskrępowanie, rodzi tę Buberowską spontaniczność, która była tak obca Eichmannowi i tysiącom innych, w sumie bardzo nieszczęśliwych, ludzi. Narodziny spontaniczności, nieskrępowania są możliwe, ponieważ sama prawda to (w szczególny sposób przezroczysta) zgodność z tym, co jest (w szczególności z tym, co się wydarza). To jarzmo nie jest ciężkie.

${ }^{50}$ Nie chcę tu twierdzić, że dla budowania tożsamości ważny jest tylko nasz stosunek do prawdy. 


\section{Fundamental Relations between Truth, Freedom, Dialogue and Personal Identity from the Perspective of the Theory of Speech (Summary)}

The article discusses the problem of relations between freedom, truth and the dialogue, and tries to establish what makes the presence of the dialogue to be a symptom of social health. Here speech is being considered in its cognitive function taken as an elementary one. Ordinary functioning of speech and the essence of the dialogue is being seen, first, in the possibility of denial, that is connected with necessary existence of ontic diversity of beings and with the trait of the speaking being as mastering over alternatives. All this conditions are at the base of freedom in its most primary meaning. The second factor that must be considered while trying to understand what constitutes the dialogue in its essence is the need for truth and the necessity of some realisations of truth. These two elements, taken jointly - the possibility of denial and the need for truth - show that the final warrantor of truth is the speaker herself/himself, and the warranty that she/he is giving as speaking is the obligation to act in accordance with her/his statement(-s). This moment of the personal, free reference to always common truth shows how personal identity is being built in the dialogue. Additionally it becomes clear how a new sense can arise with any new statement.

Keywords: dialogue; freedom; truth; personal identity; new sense.

\section{O fundamentalnych relacjach między prawdą, wolnością, dialogiem i budowaniem tożsamości - z perspektywy teorii mowy (Streszczenie)}

W tekście podjęto kwestię relacji między wolnością, prawdą i dialogiem, próbując ustalić, co sprawia, że obecność dialogu stanowi objaw zdrowia społecznego. Rozpatruje się przy tym mowę w jej funkcji poznawczej, traktowanej jako funkcja elementarna. Zwykłe funkcjonowanie mowy oraz istotę dialogu upatruje się przy tym po pierwsze $\mathrm{w}$ możliwości zaprzeczania, która wiąże się z koniecznym istnieniem ontycznej różnorodności bytów oraz z wyróżnikiem istoty mówiącej jako panującej nad alternatywami. Wszystko to funduje wolność w jej najbardziej podstawowym rozumieniu. Drugim czynnikiem, który trzeba wziąć pod uwagę, by zrozumieć, czym jest dialog $\mathrm{w}$ jego fundamentach, jest potrzeba prawdy i konieczność jakichś realizacji prawdy. Te dwa elementy widziane łącznie - możliwość zaprzeczania i potrzeba prawdy - pokazują, że ostatecznym gwarantem prawdy w każdym 
konkretnym wypadku jest sam mówiący, a gwarancja, którą swym mówieniem daje, to zobowiązanie do działań niesprzecznych $\mathrm{z}$ wypowiadaną treścią. Ten moment osobistego, wolnego odniesienia do zawsze wspólnej prawdy pokazuje, w jaki sposób w dialogu budowana jest tożsamość osobowa. Dodatkowo wyjaśnia się, jak to się dzieje, że wraz z każdym nowym powiedzeniem może pojawić się nowy sens.

Słowa kluczowe: dialog; wolność; prawda; tożsamość osobowa; nowy sens.

\section{Bibliografia}

Arendt, Hannah. Eichmann in Jerusalem. New York: Penguin Books, 1983.

Arystoteles. Metafizyka, t. I i II. Lublin: KUL, 2000.

Austin, John Langshaw. „Truth”. W: John Langshaw Austin, Philosophical Papers. Oxford: Clarendon Press, 1961.

Bachtin, Michaił. „Problem gatunków mowy”. W: Michaił Bachtin, Estetyka twórczości stownej, 348-402. Warszawa: PIW, 1986.

Bachtin, Michaił. W stronę filozofii czynu. Gdańsk: słowo/obraz terytoria, 1997.

„Bądź wolność Twoja”: Józefa Tischnera refleksja nad życiem publicznym, red. Jarosław Jagiełło, Władysław Zuziak. Kraków: Znak i PAT, 2005.

Bogusławski, Andrzej. A Study in the Linguistics-Philosophy Interface. Warszawa: Bel-Studio, 2007.

Bogusławski, Andrzej. Semantyka, pragmatyka. Leksykografa glos demarkacyjny. Warszawa: Takt, 2008.

Bogusławski, Andrzej. Roztrzasania nadlingwistyczne. Warszawa: Bel-Studio, 2011. Bogusławski, Andrzej, Ewa Drzazgowska. Język w refleksji teoretycznej. Przekroje historyczne, t. I-II. Warszawa: Katedra Lingwistyki Formalnej Uniwersytetu Warszawskiego, 2016.

Buber, Martin. Ich und Du. Stuttgart: Reclam, 1983.

Bühler, Karl. Sprachtheorie. Jena: Gustav Fischer, 1934.

Chapel, Joseph F. „Ferdinand Ebner: na początku było słowo”. Paedagogia Christiana 1/35 (2015): 99-109.

Diels, Hermann, Walther Kranz. Die Fragmente der Vorsokratiker: griechisch und deutsch. Dublin, Zürich: Weidmann, 1972, 1973.

Duraj-Nowosielska, Izabela. Robić coś i coś powodować. Opozycja agentywności i kazuatywności w języku polskim. Warszawa: Wydział Polonistyki UW, 2007.

Ebner, Ferdinand. Wort und Liebe. Berlin: LitVerlag, 2015.

Ebner, Ferdynand. Stowo i realności duchowe. Fragmenty pneumatologiczne. Chojnice: Oficyna Wydawnicza Fundacji Fuhrmanna, 2016. 
Eriugena, Jan Szkot. Periphyseon, ks. II. Kęty: Wydawnictwo Marek Derewiecki.

Frege, Gottlob. „Myśl. Studium logiczne”. W: Gottlob Frege, Pisma semantyczne, 100-129. Warszawa: PWN.

Horvitz, Rivka. „Ferdinand Ebner als Quelle von Martin Bubers Ich und Du”. W:

Untersuchungen zum „Brenner”, red. Walter Methlagl, Eberhard Sauermann, Sigurd Paul Scheichl, 283-294. Salzburg: Otto Müller, 1981.

Itkonen, Esa. Universal History of Linguistics. India, China, Arabia, Europe. Amsterdam-Philadelphia: Benjamins, 1991.

Kłoczowski, Jan Andrzej. Filozofia dialogu. Poznań: W drodze, 2011.

Konfucjusz. Dialogi konfucjańskie. Wrocław: Ossolineum,1976.

Łukasiewicz, Jan. O zasadzie sprzeczności u Arystotelesa. Warszawa: PWN, 1987.

Otto, Detlef. „Johann Georg Hamann”. W: Klassiker der Sprachphilosophie: von Platon bis Noam Chomsky, red. Tilman Borsche, 197-213. München: Beck, 1996.

Peirce, Charles Sanders. Phänomen und Logik der Zeichen. Frankfurt am Main: Suhrkamp, 1983.

Peirce, Charles Sanders. Semiotische Schriften, Bd. 1-2. Frankfurt am Main: Suhrkamp, 1986, 1990.

Platon. „Fajdros”. W: Platon, Dialogi. Warszawa: Unia Wydawnicza Verum, 1993.

Platon. Kratylos. Lublin: KUL, 1990.

Platon. „Sofista”. W: Platon, Sofista. Polityk. Warszawa: PWN, 1956.

Rosenberg, Marshall B. Porozumienie bez przemocy. O języku serca. Warszawa: Czarna Owca, 2015.

Skorulski, Krzysztof. „Ebnerowska dialogika w kontekście”. W: Ferdynand Ebner, Stowo i realności duchowe. Fragmenty pneumatologiczne, 235-295. Chojnice: Oficyna Wydawnicza Fundacji Fuhrmanna, 2016.

Skorulski, Krzysztof. „Słowo i pustosłowie”. Przegląd Pedagogiczny 1 (2013): 105-118 .

Skorulski, Krzysztof. „Aktualność i performatywność słowa”, Paedagogia Christiana 1/35 (2015): 13-40.

Spaemann, Robert. Osoby. O różnicy między czymś a kimś. Warszawa: Oficyna Naukowa, 2001.

Styczeń, Tadeusz. „Aksjologiczne podstawy kultury politycznej”. W: Sacrum i kultura. Chrześcijańskie korzenie przyszłości, red. Ryszard Rubinkiewicz, Stanisław Zięba, 167-185. Lublin: KUL, 2000.

Tischner, Józef. Etyka solidarności oraz Homo sovieticus. Kraków: Znak, 1992.

Tischner, Józef. Etyka solidarności. Kraków: Znak, 2000.

Tischner, Józef. Myśli o wolności, władzy i wspólnocie. Kraków: Znak, 2016.

Weil, Simone. Zakorzenienie i inne fragmenty. Wybór pism. Kraków: Znak, 1961.

Wittgenstein, Ludwig. Tractatus logico-philosophicus. Warszawa: PWN, 2000. 
